\title{
ACADEMICS' PERCEPTIONS OF QUALITY IN HIGHER EDUCATION IN TURKEY
}

\author{
Semra Mirici \\ Gazi University, Turkey
}

\begin{abstract}
Quality in education is one of the main concerns for governments in order to make sure the students will be able to meet the work power needs of the sector, and be able to get a job that meets their expectations in career when they graduate. In other words, it can be summarized with two words; input quality and output equality. The study aimed to investigate Turkish academics' perceptions about the quality in higher education in Turkey. The study adopted survey method based on quantitative data. The participants comprised 53 academics from different universities in Turkey, and they were selected randomly on voluntary basis. The data were collected in distance using "The Questionnaire of Academics' Perceptions of Quality in Higher Education" adapted from Rossner (2008) as a Google Form. The data were analyzed using descriptive statistics such as frequency and percentage. The results revealed that majority of academics in Turkey were in favor for accreditation, they were in the opinion that the curricula content should be designed in accordance with the $21^{\text {st }}$ century skills and market needs, and certified programs should be offered to students in an educational environment where even academics should be observed by field experts to make sure about the quality of educational practices.
\end{abstract}

Keywords: academics, accreditation, higher education, perception, quality.

\section{Introduction}

The concept of quality is associated with many parameters such as distinctiveness or desired characteristics or features by users of a product or a service or third parties (Montgomery, 2012, p. 3). Quality can be defined and evaluated in accordance with various objectives (Téllez \& Ramírez, 2012, pp. 183-196). The ultimate goal of many countries is to guarantee the optimum educational access rates for improving the quality in education.

Education quality requires a set of elements in the before, during, and after every single process of educational practices, satisfying the implicit and explicit strategic expectations (Dorrian \& Wache, 2009, p. 161). 
Educational quality is evaluated via various indicators, such as the budget allocated to education, test scores, student/teacher ratios, teacher qualifications, and the period of time students spend in their schools (Madani, 2019, p. 104). Quality evaluation needs to respond to the issue of academics' responsibility for enacting and improving academic standards, move away from acting as a mechanism of state surveillance. A point of departure is that quality evaluation needs to be turned into a support mechanism to encourage individual academic's self-regulation of teaching and learning and to develop motivational forces for improvement. Education quality is believed to ensure the cognitive development of learners; building attitudes, skills and values that are likely to enable individual well-being and social development; and equity. However, most focus still on the quantitative aspects of education (Barett, Chawla-Duggan, Lowe, Nikel \& Ukpo, 2006, pp. 6-11).

Just like in all the educational fields, higher education institutions are in need of taking initiatives to encourage academic staff to improve their teaching practice through promoting rewards activities (Cheng, 2017, pp. 160-162).

\section{Quality in higher education}

In relation to how the educational system facilitates or obstructs behavior, quality seems to be linked to goal achievement and something that needs to be evaluated, audited and controlled in order to exist within the goal-and-result oriented education system (Mufic \& Fejes, 2020, pp. 8-10).

The educational quality is based on the following principles (Nikel \& Lowe, 2010, pp. 600-602):

- Quality in education is not to be seen as a definable end-state but as a commitment throughout the system to a continuous process of adjustment,

- Educational quality is a situationally grounded attempt to 'co-optimize' the dimensions recognizing that they will be in continuously shifting relationships of tension and complementarity.

And quality education includes (UNICEF, 2000, p. 3):

- Learners who are healthy, well-nourished and ready to participate and learn, and supported in learning by their families and communities;

- Environments that are healthy, safe, protective and gender-sensitive, and provide adequate resources and facilities;

- Content that is reflected in relevant curricula and materials for the acquisition of basic skills, especially in the areas of literacy, numeracy and skills for life, and knowledge in such areas as gender, health, nutrition, HIV/AIDS prevention and peace; 
- Processes through which trained teachers use child-centered teaching approaches in well-managed classrooms and schools and skillful assessment to facilitate learning and reduce disparities; and

- Outcomes that encompass knowledge, skills and attitudes, and are linked to national goals for education and positive participation in society.

Quality in higher education may even be more difficult to define than in most other sectors. The first important step would be to agree internationally on terms such as levels, standards, effectiveness and efficiency. Such agreement on basic factors is also an objective for the so-called "Bologna process" of integration currently taking place in Europe" (Van Damme, 2001, pp. 420-430).

Quality in higher education comprises the following interrelated parameters of quality (Elten \& Stensaker, 2018, pp. 189-202):

- Management

- Quality culture \& notion of quality

- Sources of inspiration

- Employing institutional work

- Perspective to studying quality work

- Rationale for operation

- Actors' roles

- Outcomes

- Underlying logic

- Power and authority

\section{Educational Quality in Turkey}

From the OECD Report in (2011) it could be understood that ten years ago Turkey was not in a promising position (See Figure 1).

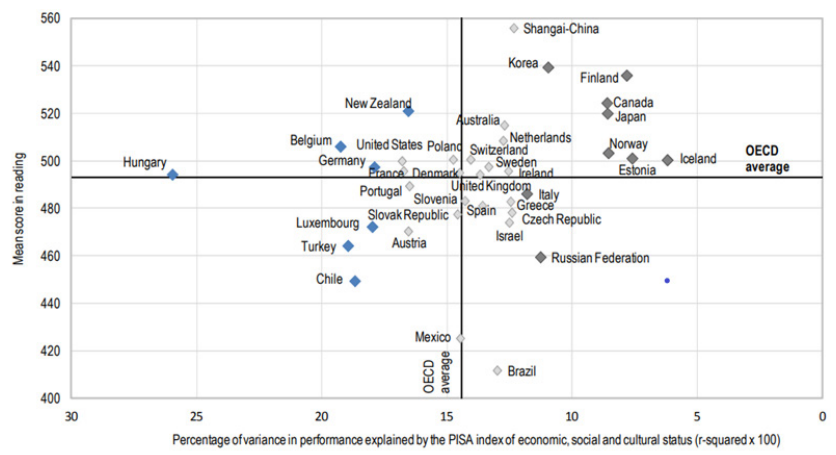

Figure 1. OECD Report in 2011 
The figure shows that Turkey is in the negative part of both quality and equity axes. The terms efficiency, effectiveness, equity and quality have often been used synonymously. Some may emphasize the quality of inputs to the education systems but others stress the quality of processes and outcomes (Cheng \& Cheung, 1997, pp. 452-454). In this perspective it can be said that the OECD report in 2011 could be one of the factors that awakened interest in educational quality in the higher education system, and lead to the establishment of Higher Education Quality Council, Turkey in 2015 (accessible at https://yokak.gov.tr/hakkinda) .

As for the time being, the meaning of quality in the area of higher education is debated as an important issue in the past few years in Turkey. For instance, an accreditation body called The Association for Evaluation and Accreditation of Teacher Education Programs (EPDAD), established in 2014, accredits the programs in the Faculties of Education in every Turkish university (accessible at https://epdad.org.tr/index.php). However, what constitutes quality has not been thoroughly clarified officially in the higher education system, and consequently, academics are confused to consider how they can define quality in their own context. As a consequence, the research question of the study was formulated as "What are the academics' perceptions of quality in Higher Education in Turkey?"

\section{Method}

The study adopted survey method based on quantitative data. Survey method is applied to describe behaviors and gather people's perceptions, opinions, attitudes, and beliefs about a current issue in education (Creswell, 2008, pp. 16-17; Lodico, Spoulding, \& Voeltge, 2010, pp. 12-20). The other details of the method are as follows:

\section{Participants}

The participants of the study comprised 53 academics from different universities in Turkey, and they were selected randomly on voluntary basis. Once the Google Form of the data collection tool (a questionnaire) was created, the link of the form was shared with academics via some social media, such as LinkedIn and WhatsApp in Turkey. They were invited to respond to the questionnaire.

\section{Data Collection and Analysis}

The data were collected using "The Questionnaire of Academics' Perceptions of Quality in Higher Education" through Google Form in distance. The questionnaire comprising 5 Likert type answers (Strongly disagree, Disagree, Neutral, Agree, Strongly Agree) was adapted from Rossner 
(2008, pp. 24-26) with some modifications. Upon modifications, a draft version was developed, and then it was sent to two field experts for their opinions. Based on the experts' opinions, it was finalized as a five point Likert type questionnaire containing two main parts and twenty-seven questions. The first part was composed of seven questions about the participants' demographic information, such as their gender, academic title, academic experience, type of institution, etc. The second part included 20 items about the participants' perception of quality in higher education. The obtained data were analyzed using descriptive statistics such as frequency and percentage via Excel program.

\section{Results}

Findings of the study are stated and illustrated as in the following:

- Findings based on the demographic information of the participants

The participants of the study comprised 53 academics in different state and private universities in Turkey. The demographic information about the participant academics is illustrated in Table 1 below.

Table 1. Demographic information of the participants

\begin{tabular}{|c|c|c|c|c|}
\hline Item & Information & Responses & $\boldsymbol{N}$ & $\%$ \\
\hline \multirow[t]{2}{*}{1} & \multirow[t]{2}{*}{ Gender } & Male & 24 & 45.30 \\
\hline & & Female & 29 & 54.70 \\
\hline \multirow[t]{2}{*}{2} & \multirow[t]{2}{*}{ Academic Status } & Part-time & 0 & 00.00 \\
\hline & & Full-time & 53 & 100.00 \\
\hline \multirow[t]{5}{*}{3} & \multirow{5}{*}{$\begin{array}{l}\text { Administrative } \\
\text { Position }\end{array}$} & Coordinator & 9 & 17.00 \\
\hline & & Head of Department & 9 & 17.00 \\
\hline & & Dean & 1 & 01.90 \\
\hline & & None & 25 & 47.20 \\
\hline & & Other & 11 & 20.80 \\
\hline \multirow[t]{4}{*}{4} & \multirow{4}{*}{$\begin{array}{l}\text { Academic } \\
\text { Experience }\end{array}$} & 1-5 years & 7 & 13.20 \\
\hline & & 6-10 years & 8 & 15.10 \\
\hline & & $10-15$ years & 14 & 26.40 \\
\hline & & $15+$ years & 24 & 45.30 \\
\hline \multirow[t]{4}{*}{5} & \multirow[t]{4}{*}{ Academic Title } & Instructor, $\mathrm{PhD}$ & 8 & 15.40 \\
\hline & & Assistant Professor & 18 & 34.60 \\
\hline & & Associate Professor & 10 & 19.20 \\
\hline & & Professor & 16 & 30.80 \\
\hline
\end{tabular}




\begin{tabular}{|l|l|l|c|c|}
\hline Item & Information & Responses & $\boldsymbol{N}$ & $\mathbf{\%}$ \\
\hline \multirow{3}{*}{6} & \multirow{2}{*}{ Institution Type } & Faculty/college & 43 & 82.70 \\
\cline { 3 - 5 } & & Vocational college & 3 & 05.80 \\
\cline { 3 - 5 } & & English prep school & 5 & 09.60 \\
\cline { 3 - 5 } & University center & 4 & 07.70 \\
\hline \multirow{3}{*}{ Field of Study } & Social Sciences & 47 & 90.40 \\
\cline { 3 - 5 } & & Natural Sciences & 3 & 05.80 \\
\cline { 3 - 5 } & & Health Sciences & 2 & 03.80 \\
\cline { 3 - 5 } & & Fine Arts & 0 & 00.00 \\
\hline
\end{tabular}

As it can be seen in the table above; majority of the participants are full time academics, have administrative positions, have more than 15 years of academic experience, are Assistant Professors, work in a faculty or a college, and are from the field of Educational Sciences.

Table 2. Perceptions of Quality in Higher Education

\begin{tabular}{|l|l|l|c|c|c|c|c|}
\hline No. & Statements & \multicolumn{2}{l}{ Disagree } & \multicolumn{2}{l}{ Neutral } & \multicolumn{2}{l|}{ Agree } \\
\cline { 3 - 8 } & & $\boldsymbol{N}$ & $\%$ & $\boldsymbol{N}$ & $\%$ & $\boldsymbol{N}$ & $\%$ \\
\hline 1 & $\begin{array}{l}\text { Educational standards and teaching } \\
\text { activities should lead to developing } \\
21^{\text {st }} \text { century skills. }\end{array}$ & 3 & 5.7 & 4 & 7.7 & 45 & 86.6 \\
\hline 2 & $\begin{array}{l}\text { All academics should work under } \\
\text { the supervision of an appropriately } \\
\text { qualified academic manager }\end{array}$ & 3 & 7.6 & 10 & 18.9 & 39 & 73.6 \\
\hline 3 & $\begin{array}{l}\text { Premises and classes should be } \\
\text { suitable for 21 } 1^{\text {st }} \text { century education. }\end{array}$ & 3 & 3.8 & 4 & 7.5 & 47 & 88.7 \\
\hline 4 & $\begin{array}{l}\text { Curriculum and syllabuses should } \\
\text { take account of the needs of } \\
\text { prospective employers. }\end{array}$ & 1 & 1.9 & 7 & 13.2 & 45 & 84.9 \\
\hline 5 & $\begin{array}{l}\text { Resources and materials should be } \\
\text { appropriate to the needs students } \\
\text { and the course objectives. }\end{array}$ & 1 & 1.9 & 5 & 9.4 & 47 & 83.7 \\
\hline 6 & $\begin{array}{l}\text { Teaching methods and techniques } \\
\text { should be appropriate and effective } \\
\text { in the teaching learning process. }\end{array}$ & 1 & 1.9 & 2 & 3.8 & 49 & 94.3 \\
\hline 7 & $\begin{array}{l}\text { There should be a regular } \\
\text { observation of teaching activities. }\end{array}$ & 3 & 9.5 & 7 & 13.2 & 41 & 77.3 \\
\hline 8 & $\begin{array}{l}\text { There should be continuous } \\
\text { professional development for all } \\
\text { academics. }\end{array}$ & 1 & 1.9 & 2 & 3.8 & 50 & 89.4 \\
\hline
\end{tabular}




\begin{tabular}{|c|c|c|c|c|c|c|c|}
\hline \multirow[t]{2}{*}{ No. } & \multirow[t]{2}{*}{ Statements } & \multicolumn{2}{|c|}{ Disagree } & \multicolumn{2}{|c|}{ Neutral } & \multicolumn{2}{|c|}{ Agree } \\
\hline & & $N$ & $\%$ & $N$ & $\%$ & $N$ & $\%$ \\
\hline 9 & $\begin{array}{l}\text { There should be opportunities for } \\
\text { students to reflect their individual } \\
\text { questions and concerns, and to } \\
\text { obtain information and advice. }\end{array}$ & 1 & 1.9 & 5 & 9.4 & 47 & 88.7 \\
\hline 10 & $\begin{array}{l}\text { Administration and auxiliary } \\
\text { services should be efficient and } \\
\text { effective. }\end{array}$ & 3 & 3.8 & 3 & 5.7 & 48 & 90.5 \\
\hline 11 & $\begin{array}{l}\text { Evaluation of and feedback in the } \\
\text { educational process should be } \\
\text { regular and appropriate. }\end{array}$ & 3 & 5.7 & 1 & 1.9 & 49 & 92.5 \\
\hline 12 & $\begin{array}{l}\text { Students should be provided with } \\
\text { additional certified educational } \\
\text { activities. }\end{array}$ & 1 & 1.9 & 6 & 11.5 & 45 & 86.5 \\
\hline 13 & $\begin{array}{l}\text { There should be platforms for } \\
\text { students to give feedback on the } \\
\text { educational process, and this } \\
\text { should be analyzed and taken } \\
\text { into account by academics and } \\
\text { administrators. }\end{array}$ & 3 & 5.7 & 4 & 7.5 & 46 & 86.8 \\
\hline 14 & $\begin{array}{l}\text { Classroom size should not exceed } \\
25 \text { students except for the lectures } \\
\text { in large conference halls. }\end{array}$ & 5 & 9.4 & 5 & 9.6 & 43 & 81.1 \\
\hline 15 & $\begin{array}{l}\text { Students should be provided } \\
\text { with activities to increase their } \\
\text { multicultural awareness. }\end{array}$ & 7 & 13.5 & 6 & 11.5 & 40 & 75.54 \\
\hline 16 & $\begin{array}{l}\text { Students should be encouraged and } \\
\text { provided with facilities to learn } \\
\text { additional languages. }\end{array}$ & 10 & 18.87 & 5 & 9.6 & 38 & 71.7 \\
\hline 17 & $\begin{array}{l}\text { There should be one to one } \\
\text { interview/ communication } \\
\text { platforms for students to prepare } \\
\text { for after university \& career life. }\end{array}$ & 7 & 13.2 & 7 & 13.2 & 39 & 73.6 \\
\hline 18 & $\begin{array}{l}\text { There should be international } \\
\text { contacts for both academics and } \\
\text { students. }\end{array}$ & 10 & 18.9 & 1 & 2 & 42 & 79.2 \\
\hline 19 & $\begin{array}{l}\text { There should be pre-determined } \\
\text { standards for both educational and } \\
\text { administrative practices. }\end{array}$ & 8 & 15.1 & 5 & 9.4 & 40 & 75.5 \\
\hline 20 & $\begin{array}{l}\text { Academic publications and } \\
\text { research projects should be } \\
\text { promoted through university funds. }\end{array}$ & 7 & 13.2 & 1 & 1.9 & 45 & 84.9 \\
\hline
\end{tabular}

As the table illustrates, in terms of the quality, majority of participants agree on providing students with activities to increase their multicultural 
awareness, motivating them to learn additional languages, preparing students for after university career life, helping students for international contacts, introducing the educational and administrative standards, and promoting publications and research projects.

\section{Discussion}

In order to understand the quality of higher education institutions, it is essential to collect data and evaluate the character of the educational processes of educational institutions and their elements; such as the relationships between academic and administrative staff at different levels and in different departments and between the staff and the students, as well as the extent to which the organization in general is prepared contribute to the educational quality of the institution and its practices (Zou \& Du \& Rasmussen, 2012, pp. 170-171; Barret, Chawla-Duggan, Lowe, Nikel, J., \& Ukpo, 2006, pp. 1-9).

In the study, academics' perception on the quality in higher education was obtained just like in the study conducted by Biggs and Tang (2011, pp. 1-418), in which each of the participants reflected their opinions in three domains or contexts (Biggs and Tang, 2011, pp. 120-125). The items in the questionnaire focused on academic, institutional, and administrative features in their institution. The study was based on the crucial information about quality by its internal processes including an element of externality (Brown, 2004, pp. 1-224). The results revealed that there was a considerable influence of social and economic situations on the quality of educational provision as it was the case in the study conducted by Tavassoli, Welch, and Houshyar (2000, pp. 279-304).

\section{Conclusions}

In conclusion, based on the data obtained, it can be inferred that accreditation plays a significant role in the quality of a higher education institution. The curricula content should be designed in accordance with the $21^{\text {st }}$ century skills and the needs of the prospective employers should be considered while planning the contents. In addition, certified programs can be one of the components to help students prepare for their future career, and in the educational process observing academics might be helpful to make sure about the quality of educational practices. It can also be recommended that students be provided with the activities to increase their multicultural awareness, motivating them to learn additional languages, guiding students for international contacts, and promoting publications and research projects in the university. 


\section{References}

Akareem, H. S., \& Hossain, S. S. (2016). Determinants of education quality: what makes students' perception different? Open Review of Educational Research, 3(1), 52-67.

Barratt, A., Chawla-Duggan, R., Lowe, J., Nikel, J., \& Ukpo, E. (2006). The concept of quality in education: a review of the 'international' literature on the concept of quality in education. (EdQual Working Papers; No. 3). University of Bristol. Retrieved from: https:// www.edqual.org/publications/workingpaper/edqualwp3.pdf/at_download/file.pdf

Biggs, J., \& Tang, C. (2011). Teaching for quality learning at university (4 ${ }^{\text {th }}$ ed.). New York: Open University Press.

Brown, R. (2004). Quality assurance in higher education: The UK experience since 1992. New York: Routledge.

Cheng, M. (2017). Reclaiming quality in higher education: a human factor approach. Quality in Higher Education, 23(2), 153-167.

Cheng, Y. C., \& Cheung, W. M. (1997). Multi-Models of Education Quality and MultiLevels of Self-Management in Schools. Educational Management \& Administration, 25(4), 451-462.

Creswell, J. W. (2008). Educational research planning, conducting, and evaluating quantitative and qualitative research. Boston: Pearson. Retrieved from: http://lcwu.edu. pk/ocd/cfiles/TESOL/MS-TSL-505/EducationalResearchPlanningConductingandEvaluatingQuantitativeandQualitativeResearch.pdf

Dorrian, J., \& Wache, D. (2009). Introduction of an online approach to flexible learning for on-campus and distance education students: Lessons learned and ways forward. Nurse Education Today, 29(2), 157-167.

Elten, M. \&Stensaker, B. (2018). Conceptualising 'quality work' in higher education. Quality in Higher Education, 24(3), 189-202.

Garvin, D. A. (1988) Managing Quality: The Strategic and Competitive Edge. The Free Press, New York. Retrieved from: https://www.scirp.org/(S(czeh2tfqyw2orz553k1w0r45))/ reference/ReferencesPapers.aspx?ReferenceID $=1917060 \&$ utm_campaign $=29653$ 3276_16801096996\&utm_source $=$ lixiaofang\&utm_mediu $M=$ adwords\&utm_ter $M=$ \&utm_content $=$ aud-919698560781:dsa-489862000788_c__1012764_b\&gclid $=$ Cj0KCQ iAmL-ABhDFARIsAKywVaetXcZIgHQvbPpUrOHxhO_0-mkaFiZ-zFhQmHc8fsbqfVuDMd6v1vEaAkZXEALw_wcB

Hill, Y., Lomas, L. and MacGregor, J. (2003), "Students' perceptions of quality in higher education" Quality Assurance in Education, 11(1), 15-20.

Lagrosen, S., Seyyed-Hashemi, R., \&Leitner, M. (2004). Examination of the dimensions of quality in higher education. Quality Assurance in Education, 12(2), 61-69.

Lodico, M., Spaulding, D., \&Voegtle, K. (2010). Methods in educational research: From theory to practice ( $2^{\text {nd }}$ ed.). San Francisco: Jossey-Bass.

Madani, R. A. (2019). Analysis of Educational Quality, a Goal of Education for All Policy. Higher Education Studies, 9(1), 100-109.

Montgomery, D. C. (2012) Introduction to Statistical Quality Control. John Wiley\&Son

Mufic, J., \&Fejes, A. (2020). 'Lack of quality' in Swedish adult education: a policy study. Journal of Education Policy, 1-16. Retrieved from: https://www.tandfonline.com/doi/ full/10.1080/02680939.2020.1817567

Nikel, J., \& Lowe, J. (2010). Talking of fabric: A multi-dimensional model of quality in education. Compare, 40(5), 589-605. 
OECD (2011). Against the odds. Paris: OECD.

Rossner, R. (2008). Quality assurance in the provision of language education and training for adult migrants - guidelines and options. The European Association for Quality Language Services (EAQUALS). Retrieved from: https://rm.coe.int/16802fc1da

Tavassoli, G. A., Welch, A. R., \& Houshyar, K. (2000). The struggle for quality and equality in Iranian education: Problems, progress, and prospects. In A. R. Welch (Ed.), Third world education. New York: Garland Publishing.

Téllez, F., \&Ramírez, M. J. (2012). Education Quality. In C. Acedo, D. Adams, \& S. Popa (Eds.), Quality and Qualities: Tensions in Education Reforms. Springer Sense Publishers.

UNICEF. (2020). Defining quality in education. New York: UNICEF.

Van Damme, D. (2001). Quality Issues in the Internationalisation of Higher Education. Higher Education, 41(4). Retrieved from: https://www.jstor.org/stable/3448132

Zou, Y., \& Du, X., \& Rasmussen, P. (2012). Quality of higher education: organizational or educational? A content analysis of Chinese university self-evaluation reports. Quality in Higher Education, 18(2), 169-184. 